\title{
Pengembangan Buku Ajar Fisika Berbasis Science, Technology, Engineering, and Mathematics (STEM) pada Pokok Bahasan Suhu dan Kalor di SMA
}

\author{
Elvia Puspitasari ${ }^{1 *}$, Pramudya Dwi Aristya Putra ${ }^{2}$, dan Rif'ati Dina Handayani ${ }^{3}$ \\ ${ }_{1 * 2,3}$ Pendidikan Fisika, Fakultas Keguruan dan Ilmu Pendidikan \\ Universitas Jember, Jawa Timur - Indonesia \\ *E-mail Penulis Korespondensi: elviapuspita03@gmail.com
}

\begin{abstract}
Abstrak
Pengembangan buku ajar fisika berbasis Science, Technology, Engineering, and Mathematics (STEM) pada pokok bahasan suhu dan kalor di SMA bertujuan untuk menghasilkan buku ajar fisika berbasis STEM yang valid dan mendeskripsikan respon siswa terhadap buku ajar yang telah dikembangkan. Desain penelitian pengembangan yang digunakan yaitu mengacu pada model ADDIE yang terdiri dari lima tahapan meliputi Analyze, Design, Development, Implementation, dan Evaluation. Buku ajar yang telah dikembangkan dilakukan penilaian kelayakan produk oleh validator ahli dan pengguna. Hasil validasi buku ajar fisika berbasis STEM berkategori sangat valid dengan tingkat validitas mencapai $86,2 \%$. Hasil respon siswa menunjukkan respon sangat positif dengan nilai persentase respon siswa mencapai $90,98 \%$. Berdasarkan hasil perolehan validitas dan respon siswa, maka buku ajar fisika berbasis STEM pada pokok bahasan suhu dan kalor berkategori sangat valid dan mendapat respon sangat baik dari siswa. Penelitian ini diharapkan dapat bermanfaat sebagai referensi sumber belajar bagi guru dan siswa dalam kegiatan pembelajaran di SMA.
\end{abstract}

Kata kunci: Pengembangan, Buku Ajar, STEM, Validitas, Respon

\section{Abstract}

The development of physics textbooks based on Science, Technology, Engineering, and Mathematics (STEM) on the subject of temperature and heat in senior high school aims to produce valid STEM-based physics textbooks and describe student's responses to the textbooks that have been developed. The development research design used refers to the ADDIE model which consists of five stages that include Analyze, Design, Development, Implementation, and Evaluation. Textbooks that have been developed given a product eligibility assessment by expert validators and users. The validation results of physics textbooks based STEM were categorized as very valid with a validity level of $86.2 \%$. The results of student responses showed very positive responses with the proportion value of student responses reaching $90.98 \%$. Based on the results of obtaining validity and student responsibility, the physics textbook based STEM on the subject of temperature and heat is categorized as very valid and gets a very good response from students. This research is expected to be useful as a reference for learning resources for teachers and students in learning activities in senior high school.

Keywords: Development, Textbooks, STEM, Validity, Response

$\begin{array}{lll}\text { Article History: } & \text { Received: } 23 \text { April } 2021 & \text { Revised: } 27 \text { April } 2021 \\ & \text { Accepted: } 25 \text { April } 2021 & \text { Published: } 30 \text { April } 2021\end{array}$

How to cite: Puspitasari, E., Putra, P.D.A., \& Handayani, R.D. (2021). Pengembangan Buku Ajar Fisika Berbasis Science, Technology, Engineering, and Mathematics (STEM) pada Pokok Bahasan Suhu dan Kalor di SMA, Jurnal Literasi Pendidikan Fisika, 2 (1). pp. 44-52 Retrieved from http://jurnal.fkip.unmul.ac.id/index.php/JLPF

Copyright (C) April 2021, Jurnal Literasi Pendidikan Fisika 
Pengembangan Buku Ajar...

\section{PENDAHULUAN}

Salah satu permasalahan yang sering terjadi dalam pembelajaran fisika yaitu pembelajaran yang cenderung berpusat pada guru serta minimnya inovasi yang dilakukan oleh guru (Suryana et al, 2017). Kegiatan belajar mengajar yang berorientasi pada guru mengakibatkan peserta didik menjadi pasif. Proses pembelajaran lebih cenderung pada menghafal konsep dibandingkan dengan pemahaman konsep serta banyak tenaga pendidik yang menekankan pada tercapainya target materi kurikulum (Aristawati et al, 2018). Guru hendaknya merancang pembelajaran dengan menggunakan strategi, pendekatan, dan metode yang efektif untuk diterapkan dalam mengembangkan keterampilan siswa. Oleh sebab itu diperlukan suatu pendekatan pembelajaran yang menekankan pada aktivitas siswa dalam belajar fisika.

Pendekatan pembelajaran STEM merupakan pendekatan pembelajaran yang menekankan pada keterampilan siswa dalam memecahkan permasalahan dalam kehidupan sehari-hari (Moore, 2014). STEM dapat didefinisikan sebagai pendekatan yang menggabungkan teori dan praktek dengan menggabungkan empat disiplin ilmu serta pengalaman langsung di dunia nyata (Bozkurt et al, 2019). Pendekatan STEM menekankan pada integrasi dari keempat bidang ilmu yaitu Sains, Teknologi, Engineering, dan Matematika dalam suatu proses pembelajaran. Integrasi keempat bidang ilmu tersebut, menjadikan siswa tidak hanya memiliki pemahaman konsep fisika dan matematis saja, namun siswa juga memiliki pemahaman konsep mengenai proses dan prinsip dari teknologi serta kemampuan berinovasi melalui proses engineering. Implementasi pendekatan STEM dalam proses pembelajaran dapat dilakukan melalui pemanfaatan bahan ajar.

Pada umumnya, integrasi STEM serta tema kontekstual dalam kehidupan sehari-hari masih belum diangkat dalam bahan ajar yang ada saat ini (Rusyati et al, 2019). Bahan ajar yang dipakai sekolah pada umumnya berbentuk buku cetak kurikulum 2013 yang diterbitkan oleh pemerintah maupun swasta yang belum terlihat adanya integrasi STEM (Yuanita dan Kurnia, 2019). Pengembangan bahan ajar berbasis STEM dilakukan pada pokok bahasan suhu dan kalor dikarenakan materi suhu dan kalor memiliki banyak konsep sehingga dapat menimbulkan pemikiran-pemikiran yang berbeda bagi setiap siswa serta materi ini merupakan salah satu materi utama untuk siswa dalam memahami konsep-konsep fisika lainnya yang saling berkaitan.

Penelitian yang terkait dengan pengembangan bahan ajar berbasis STEM yaitu penelitian oleh Sugianto et al (2018) mendapatkan hasil bahwa modul IPA berbasis proyek yang terintegrasi dengan STEM pada materi tekanan dinyatakan layak untuk digunakan dengan tingkat validitas sebesar $87,7 \%$ dan berkategori sangat valid serta mendapat respon yang sangat baik dari siswa. Penelitian Nessa et al (2017) mendapatkan hasil bahwa buku siswa materi jarak pada ruang dimensi tiga berbasis Science, Technology, Engineering, and Mathematics (STEM) problem based learning tergolong buku siswa yang valid dan praktis. Pangesti et al (2017) dalam penelitiannya menunjukkan bahwa bahan ajar berbasis STEM termasuk ke dalam kategori layak digunakan dan dapat meningkatkan penguasaan konsep siswa. Perbedaan penelitian yang dilakukan oleh peneliti dengan penelitian sebelumnya yaitu peneliti mengembangkan buku ajar fisika berbasis STEM pada pokok bahasan suhu dan kalor.

Berdasarkan uraian diatas, maka dibutuhkan suatu penelitian untuk mengatasi kesulitan implementasi pembelajaran STEM dengan pengembangan buku ajar fisika berbasis STEM pada pokok bahasan suhu dan kalor. Penelitian ini bertujuan untuk menghasilkan buku ajar fisika berbasis STEM yang valid pada pokok bahasan suhu dan kalor di SMA dan mendeskripsikan respon siswa terhadap buku ajar fisika berbasis STEM pada pokok bahasan suhu dan kalor di SMA.

\section{METODE}

Jenis penelitian ini yaitu penelitian pengembangan yang bertujuan untuk menghasilkan produk berupa buku ajar yang valid digunakan dalam pembelajaran dan mendeskripsikan respon siswa setelah menggunakan buku ajar fisika berbasis STEM. Produk yang dikembangkan yaitu buku ajar fisika berbasis STEM pada pokok bahasan suhu dan kalor. Penelitian ini dilakukan di SMAN 1 Gambiran pada semester genap tahun ajaran

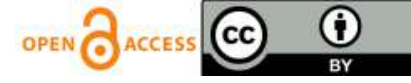


Pengembangan Buku Ajar...

2020/2021. Desain penelitian pengembangan yang digunakan dalam penelitian ini yaitu model ADDIE. Model ADDIE dapat digunakan untuk berbagai bentuk produk pengembangan misalnya modul, buku ajar, video pembelajaran, multimedia, dan sebagainya (Tegeh et al, 2014: 41). Model ADDIE merupakan model pengembangan yang terdiri dari lima tahap yaitu Tahap Analyze (Analisis), Tahap Design (Perancangan), Tahap Development (Pengembangan), Tahap Implementation (Implementasi), dan Tahap Evaluation (Evaluasi).
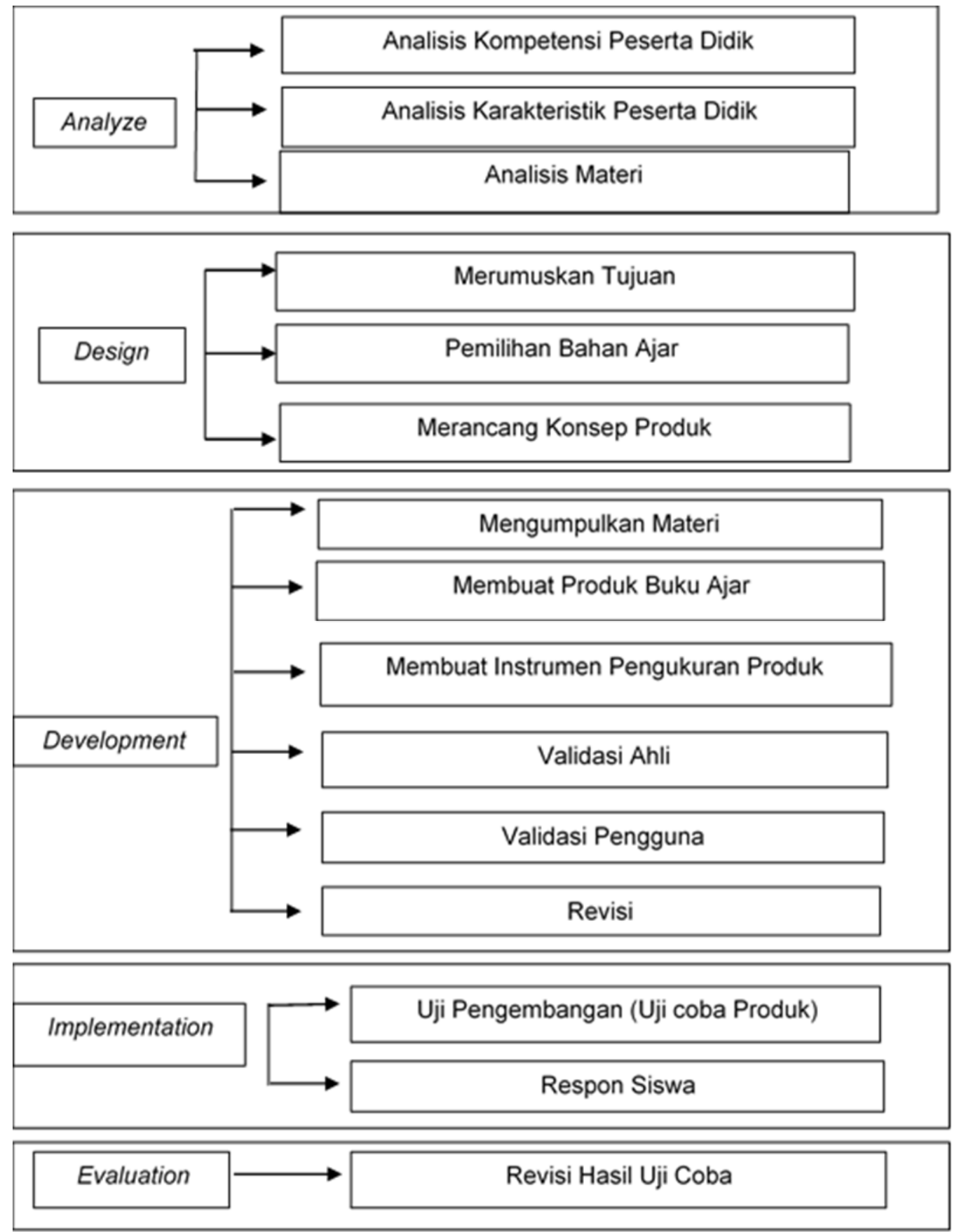

Gambar 1. Tahap Penelitian dengan Model Pengembangan ADDIE

Tahap Analyze (Analisis) digunakan untuk merumuskan konsep-konsep yang akan digunakan dalam pengembangan bahan ajar. Tahap ini dilakukan dengan beberapa langkah yaitu analisis kompetensi peserta

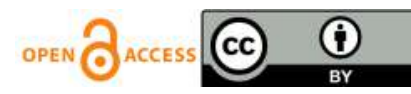


Pengembangan Buku Ajar...

didik, analisis karakteristik peserta didik, dan analisis materi. Analisis ini dilakukan untuk memperoleh informasi terkait dengan kompetensi yang harus dikuasai oleh siswa, karakteristik siswa, serta materi yang akan disajikan dalam bahan ajar. Hasil analisis digunakan sebagai dasar dalam pengembangan bahan ajar.

Tahap Design (Perancangan) dimulai dengan merumuskan tujuan pembelajaran, pemilihan bahan ajar, dan merancang konsep produk. Perumusan tujuan pembelajaran dan pemilihan bahan ajar dilakukan untuk menentukan design buku ajar yang tepat untuk mencapai tujuan tersebut. Pada tahap ini diperoleh rancangan konsep produk yang akan dikembangkan yaitu buku ajar yang didesain dengan menekankan pada integrasi dari aspek-aspek STEM.

Tahap Development (Pengembangan) yaitu berupa kegiatan realisasi dari rancangan produk. Rancangan konsep produk yang telah dibuat sebelumnya direalisasikan menjadi produk melalui beberapa tahapan yaitu mengumpulkan materi, membuat produk, membuat instrument kelayakan produk, serta validasi dan revisi. Materi yang disusun dalam buku ajar yaitu materi suhu dan kalor yang terdiri dari 6 sub pokok bahasan meliputi suhu, pemuaian, kalor, perubahan wujud, asas black, dan perpindahan kalor. Pada tahap ini, produk yang telah dikembangkan selanjutnya dilakukan validasi untuk menilai kelayakan produk dan menghasilkan produk yang telah valid.

Tahap Implementation (Implementasi) dilakukan dengan uji pengembangan buku ajar fisika berbasis STEM pada pokok bahasan suhu dan kalor di SMA. Uji coba ini dilakukan kepada siswa kelas XI MIPA 4 sejumlah 27 siswa dengan 19 siswa perempuan dan 8 siswa laki-laki. Setelah mempelajari buku ajar fisika berbasis STEM, siswa memberikan tanggapannya terhadap buku ajar fisika berbasis STEM dengan mengggunakan angket respon siswa.

Tahap Evaluation (Evaluasi) merupakan tahap untuk mengukur keberhasilan penggunaan buku ajar fisika berbasis STEM. Tahap ini dilakukan dengan melakukan analisis data yang didapatkan pada saat uji pengembangan buku ajar di sekolah. Hasil yang didapatkan pada tahap ini digunakan untuk memberi evaluasi terhadap buku ajar fisika berbasis STEM.

Instrumen pengumpulan data yang digunakan pada penelitian ini terdiri dari lembar validasi dan angket respon siswa. Validasi buku ajar fisika berbasis STEM dilakukan oleh dua validator ahli dan satu validator pengguna. Validator diminta memberikan penilaian langsung pada setiap aspek yang terdapat pada lembar validasi. Penilaian validitas buku ajar terdiri dari tiga aspek yaitu aspek konstruk, aspek isi, dan aspek bahasa. Hasil validasi tersebut digunakan untuk memperbaiki buku ajar fisika berbasis STEM. Penilaian tingkat validitas buku ajar fisika berbasis STEM yaitu sebagai berikut.

Penilaian oleh validator ahli dan pengguna

$V_{a}=\frac{T S_{e}}{T S_{h}} \times 100 \%$

Keterangan :

$\mathrm{Va} \quad$ : nilai yang didapatkan dari validator

TSe : total skor yang diperoleh

TSh : total skor maksimal

Validitas buku ajar didasarkan pada rata-rata skor total dengan kriteria validitas pada Tabel 1 berikut ini.

Tabel 1. Kriteria Tingkat Validitas

\begin{tabular}{cc}
\hline KRITERIA VALIDASI & KATEGORI \\
\hline $85,01 \%-100,00 \%$ & Sangat Valid \\
\hline $70,01 \%-85,00 \%$ & Cukup Valid \\
\hline $50,01 \%-70,00 \%$ & Kurang Valid \\
\hline $01,00 \%-50,00 \%$ & Tidak Valid \\
\hline
\end{tabular}

(Akbar, 2015: 41)

Data yang didapat dari angket respon siswa diolah dalam bentuk deskriptif persentase. Penilaian kriteria respon siswa terhadap buku ajar berbasis STEM yaitu sebagai berikut. 
Pengembangan Buku Ajar...

$N P=\frac{A}{B} \times 100 \%$

Keterangan :

$N P$ : nilai persentase respon siswa

$A$ : proporsi siswa yang memilih setuju

$B$ : jumlah siswa

Respon siswa didasarkan pada nilai persentase dengan kategori respon siswa pada Tabel 2 berikut ini.

Tabel 2. Kategori Respon Siswa

\begin{tabular}{cc}
\hline $\begin{array}{c}\text { Interval Nilai Respon } \\
\text { Siswa }\end{array}$ & Kategori \\
\hline $80 \%<\mathrm{NP} \leq 100 \%$ & Sangat Positif \\
\hline $60 \%<\mathrm{NP} \leq 80 \%$ & Positif \\
\hline $40 \%<\mathrm{NP} \leq 60 \%$ & Cukup Positif \\
\hline $20 \%<\mathrm{NP} \leq 40 \%$ & Kurang Positif \\
\hline $\mathrm{NP} \leq 20 \%$ & Sangat Kurang \\
& Positif \\
\hline
\end{tabular}

(Arikunto, 2010)

\section{HASIL DAN PEMBAHASAN}

HASIL

Produk yang dikembangkan dalam penelitian ini yaitu buku ajar fisika berbasis Science, Technology, Engineering, and Mathematics (STEM) pada pokok bahasan suhu dan kalor. Buku ajar fisika berbasis STEM dikembangkan untuk dapat digunakan sebagai bahan ajar bagi guru dan sumber belajar bagi siswa. Buku ajar fisika berbasis STEM divalidasi oleh tiga validator yang terdiri dari dua validator ahli dan satu validator pengguna. Hasil analisis validasi ahli dan pengguna terhadap buku ajar fisika berbasis STEM dapat dilihat pada Tabel 3 berikut ini.

Tabel 3. Hasil Validasi Buku Ajar Fisika Berbasis STEM

\begin{tabular}{|c|c|c|c|}
\hline Aspek & Skor & Persentase Validitas & Tingkat Validitas \\
\hline Konstruk & 4,37 & & \\
\hline Isi & 4,2 & $86,2 \%$ & Sangat Valid \\
\hline Bahasa & 4,33 & & \\
\hline
\end{tabular}

Buku ajar yang telah dikembangkan dalam bentuk produk final dan telah dikatakan valid oleh validator ahli dan pengguna selanjutnya dilakukan uji coba kepada siswa. Setelah mempelajari buku ajar fisika berbasis STEM, siswa memberikan tanggapannya terhadap buku ajar fisika berbasis STEM dengan menggunakan angket respon siswa. Adapun hasil analisis angket respon siswa dapat dilihat pada Tabel 4 berikut ini.

Tabel 4. Hasil Angket Respon Siswa

\begin{tabular}{ccc}
\hline Aspek & $\begin{array}{c}\text { Nilai Respon } \\
\text { Siswa }\end{array}$ & Kategori \\
\hline Efektifitas & $91,67 \%$ & Sangat Positif \\
\hline Isi & $84,45 \%$ & Sangat Positif \\
\hline Penyajian & $93,33 \%$ & Sangat Positif \\
\hline Bahasa & $94,45 \%$ & Sangat Positif \\
\hline Rata-rata & $90,98 \%$ & Sangat Positif \\
\hline
\end{tabular}

\section{PEMBAHASAN}

Penelitian ini merupakan penelitian pengembangan dengan mengacu pada model pengembangan ADDIE. Produk yang dikembangkan dalam penelitian ini yaitu buku ajar fisika berbasis Science, Technology, Engineering, and Mathematics (STEM) pada pokok bahasan suhu dan kalor. Berdasarkan langkah-langkah pengembangan model ADDIE, hasil pengembangan dapat dijabarkan sebagai berikut.

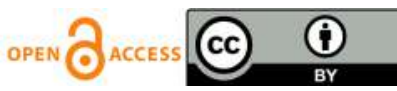


Pengembangan Buku Ajar...

Tahap analyze (analisis) dilakukan dengan observasi proses pembelajaran di kelas. Analisis ini meliputi analisis kompetensi peserta didik, karakteristik peserta didik, dan materi. Berdasarkan hasil observasi yang dilakukan, siswa lebih sering belajar fisika menggunakan rumus dan menyelesaikan soal-soal fisika, namun belum mengkaitkan penerapan konsep fisika dalam kehidupan sehari-hari. Selain itu, sumber belajar yang digunakan di sekolah yaitu berupa LKS yang berisi materi secara ringkas. Selanjutnya dilakukan analisis materi melalui studi literatur sehingga diperoleh referensi terkait dengan materi yang akan disajikan dalam bahan ajar.

Pada tahap design (perancangan) dihasilkan rancangan konsep dari produk yang dikembangkan. Tahap ini diawali dengan perumusan tujuan pembelajaran berdasarkan kompetensi inti dan kompetensi dasar yang selanjutnya dituangkan dalam bentuk peta konsep. Peta konsep ini menggambarkan sub pokok bahasan yang disajikan dalam buku ajar. Setelah merumuskan tujuan pembelajaran dan memilih bahan ajar, yaitu merancang konsep dari produk. Buku ajar fisika berbasis STEM dirancang dengan desain yang dilengkapi dengan gambar ilustrasi dan integrasi STEM yang disajikan secara terpisah pada setiap aspek-aspeknya dengan warna yang berbeda. Integrasi dari STEM meliputi aspek sains yang terletak pada pembahasan materi di setiap subbab, aspek teknologi terletak pada pembahasan penerapan konsep fisika, aspek engineering terletak pada informasi mengenai desain dan cara kerja dari teknologi yang berkaitan dengan konsep fisika, aspek matematika terletak pada perhitungan pada setiap subbab, serta dilengkapi dengan problem-problem STEM.

Tahap development (pengembangan) diperoleh buku ajar fisika berbasis STEM yang telah disusun. Buku ajar fisika berbasis STEM terdiri dari tiga bagian, yaitu: 1) bagian awal meliputi halaman cover, kata pengantar, daftar isi, daftar gambar, kompetensi inti dan kompetensi dasar, indikator pencapaian kompetensi dan tujuan pembelajaran, serta peta konsep; 2) bagian isi meliputi pendahuluan, materi yang disajikan dari aspek science dan technology, science, engineering dan mathematics problem, serta contoh soal; 3) bagian akhir meliputi rangkuman dan latihan soal. Buku ajar fisika berbasis STEM yang telah selesai disusun selanjutnya divalidasi untuk mengetahui tingkat kelayakan buku ajar yang dikembangkan.

Validasi buku ajar fisika berbasis STEM dilakukan oleh dua validator ahli dan satu validator pengguna. Aspek penilaian kelayakan produk terdiri dari 3 aspek yaitu aspek konstruk, aspek isi, dan aspek bahasa. Aspek konstruk bertujuan untuk memberikan penilaian terhadap komponen isi dalam buku ajar dan kualitas penyajian materi. Aspek isi bertujuan untuk memberikan penilaian dari segi pembaharuan dan kebutuhan. Aspek bahasa bertujuan untuk memberikan penilaian terhadap penggunaan bahasa dan tingkat keterbacaan buku ajar fisika berbasis STEM.

Aspek konstruk memperoleh rata-rata skor sebesar 4,37 dengan persentase kevalidan sebesar $87,4 \%$. Berdasarkan kriteria tingkat validitas buku ajar, aspek konstruk termasuk dalam kategori sangat valid. Hasil ini menunjukkan bahwa komponen isi dan penyajian materi dalam buku ajar fisika berbasis STEM sudah tepat. Aspek isi memperoleh rata-rata skor sebesar 4,22 dengan persentase kevalidan sebesar $84,4 \%$ termasuk ke dalam kategori cukup valid. Hal ini menunjukkan bahwa buku ajar fisika berbasis STEM dapat mendukung tujuan pendidikan saat ini yang menekankan pada keterampilan abad 21 melalui integrasi STEM yang terdapat dalam buku ajar. Sedangkan aspek bahasa memperoleh rata-rata skor sebesar 4,33 dengan persentase kevalidan sebesar $86.6 \%$. Perolehan rata-rata skor aspek bahasa termasuk dalam kategori sangat valid. Hal ini menunjukkan bahwa penggunaan bahasa dalam buku ajar fisika berbasis STEM sudah tepat serta memenuhi aspek keterbacaan.

Hasil validasi buku ajar fisika berbasis STEM yang diperoleh dari validator ahli dan pengguna yaitu sebesar $86,2 \%$. Berdasarkan kriteria tingkat validitas bahan ajar, nilai validitas dengan rentang skor $85,01 \%$ hingga $100,00 \%$ dikategorikan sangat valid dan dapat digunakan tanpa revisi. Dengan demikian, buku ajar fisika berbasis STEM pada pokok bahasan suhu dan kalor tergolong dalam kategori sangat valid dan dapat digunakan untuk uji pengembangan. Hal tersebut sesuai dengan hasil penelitian Sugianto et al (2018) yang menunjukkan bahwa modul IPA berbasis proyek terintegrasi STEM termasuk dalam kategori sangat layak meliputi kelayakan isi, kelayakan penyajian dan kelayakan kebahasaan. Selain itu, hasil penelitian Pangesti et al (2017) juga menunjukkan bahwa bahan ajar berbasis STEM yang dikembangkan termasuk dalam kategori layak yang meliputi penilaian aspek isi, aspek penyajian, dan aspek bahasa. Penelitian oleh Nessa et al (2017) mengenai pengembangan buku siswa berbasis STEM problem based learning menunjukkan bahwa buku siswa termasuk

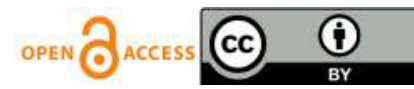


Pengembangan Buku Ajar...

dalam kategori valid, praktis, dan berpengaruh terhadap hasil belajar siswa. Penilaian validitas meliputi aspek konten yang digunakan untuk melihat kesesuaian dari materi, aspek konstruk untuk melihat kesesuaian aspekaspek STEM, dan aspek bahasa untuk melihat kesesuaian penggunaan bahasa. Buku ajar fisika berbasis STEM yang telah divalidasi dapat dilihat pada Gambar 2.
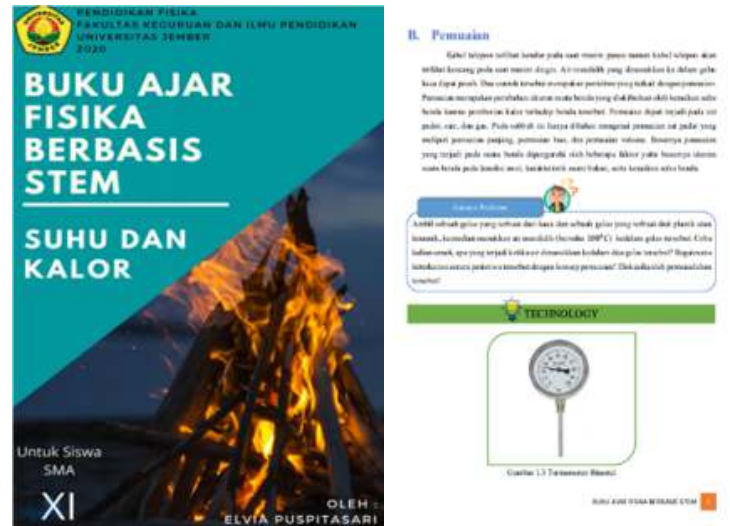

Gambar 2. Buku Ajar Fisika Berbasis STEM

Pada tahap implementation (implementasi), buku ajar fisika berbasis STEM dalam bentuk produk final dan telah dikatakan valid oleh validator sehingga selanjutnya dilakukan uji coba kepada siswa. Pada tahap uji pengembangan dilakukan dengan memberikan buku ajar fisika berbasis STEM dan angket respon kepada siswa. Angket respon siswa yang telah dibagikan pada saat uji pengembangan digunakan sebagai evaluasi tehadap buku ajar fisika berbasis STEM.

Tahap evaluation (evaluasi) dilakukan dengan menganalisis hasil angket respon siswa. Hasil analisis ini digunakan untuk mengetahui respon siswa setelah menggunakan buku ajar fisika berbasis STEM. Setelah siswa mempelajari buku ajar fisika berbasis STEM secara menyeluruh, siswa diberikan angket respon untuk memberikan tanggapannya terhadap buku ajar fisika berbasis STEM. Aspek-aspek yang dianalisis pada angket respon siswa yaitu aspek efektifitas, aspek isi, aspek penyajian, dan aspek bahasa.

Berdasarkan hasil analisis angket respon siswa, dapat diketahui bahwa nilai respon siswa pada setiap aspek termasuk dalam kategori respon sangat positif. Hasil respon siswa pada aspek efektifitas memperoleh persentase sebesar $91,67 \%$ yang termasuk dalam kategori respon sangat positif. Menurut arikunto (2010) apabila nilai persentase respon siswa berkisar antara $80 \%<N P \leq 100 \%$ maka termasuk pada kategori respon sangat positif. Hal tersebut menunjukkan bahwa buku ajar fisika berbasis STEM dapat memfasilitasi siswa memahami materi suhu dan kalor dan integrasinya dengan STEM. Aspek isi memperoleh persentase sebesar $84,45 \%$ berkategori sangat positif yang menunjukkan bahwa buku ajar fisika berbasis STEM dapat membantu siswa memahami keterkaitan materi berbasis STEM dalam kehidupan sehari-hari.

Aspek penyajian dan bahasa masing-masing memperoleh persentase sebesar $96,33 \%$ dan $94,45 \%$ dengan kategori sangat positif. Hal ini menunjukkan bahwa siswa merespon sangat baik terhadap desain, sampul, gambar, ilustrasi dan penyajian materi serta penggunaan bahasa dan kalimat yang mudah dipahami dapat membantu siswa memahami materi. Dengan demikian, hasil angket respon siswa memperoleh rata-rata skor sebesar $90,98 \%$ dengan kriteria sangat positif yang menunjukkan bahwa siswa merespon sangat baik mengenai tampilan, desain, isi maupun materi pada buku ajar fisika berbasis STEM.

Berdasarkan hasil yang diperoleh, menunjukkan bahwa buku ajar fisika berbasis STEM dapat memenuhi kebutuhan siswa dilihat dari respon positif yang diberikan oleh siswa. Hal tersebut sesuai dengan beberapa penelitian yang relevan mengenai pengembangan bahan ajar berbasis STEM yaitu penelitian oleh Almuharomah et al (2019) yang menunjukkan bahwa siswa memberikan respon baik terhadap modul fisika STEM terintegrasi kearifan lokal dan mampu meningkatkan kemampuan berpikir kreatif. Selain itu, penelitian oleh Syahirah et al (2020) menunjukkan bahwa siswa dapat menerima dengan baik modul elektrokimia berbasis STEM dengan kategori respon sangat baik. Tahapan STEM yang disajikan dalam modul dapat memudahkan

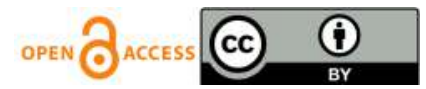


Pengembangan Buku Ajar...

siswa untuk memahami materi serta desain yang menarik dapat memotivasi siswa belajar mandiri dan menambah wawasan. Penelitian oleh Rachmawati et al (2017) juga menunjukkan bahwa hasil angket penilaian mahasiswa terhadap modul kimia dasar berbasis STEM problem based learning termasuk dalam kategori sangat praktis atau tinggi. Modul yang dikembangkan termasuk dalam kategori valid dan praktis dengan model penelitian menggunakan model ADDIE.

Dengan adanya buku ajar fisika berbasis STEM ini diharapkan dapat membantu siswa agar memiliki pemahaman konsep mengenai proses dan prinsip dari teknologi serta kemampuan berinovasi melalui proses engineering yang disajikan dalam buku ajar. Selain itu, melalui buku ajar ini diharapkan dapat membantu untuk meningkatkan kompetensi dari siswa. Pengembangan buku ajar berbasis STEM diharapkan dapat menjadi referensi sumber belajar yang digunakan dalam kegiatan pembelajaran di sekolah.

\section{PENUTUP}

Berdasarkan data yang telah diperoleh dari hasil pengembangan buku ajar fisika berbasis STEM, maka dapat diambil kesimpulan sebagai berikut: (1) validitas buku ajar fisika berbasis Science, Technology, Engineering, and Mathematics (STEM) pada pokok bahasan suhu dan kalor di SMA berkategori sangat valid dengan nilai sebesar $86,2 \%$, dan (2) respon siswa terhadap buku ajar fisika berbasis Science, Technology, Engineering, and Mathematics (STEM) pada pokok bahasan suhu dan kalor di SMA berkategori respon sangat positif dengan persentase sebesar 90,98\%. Adapun saran yang dapat diberikan berdasarkan hasil pengembangan yang telah dilakukan yaitu buku ajar fisika berbasis STEM pada pokok bahasan suhu dan kalor perlu diimplementasikan ke beberapa kelas maupun sekolah yang berbeda sehingga dapat mengetahui tingkat efektifitasnya maupun respon siswa dan sebelum memberikan buku ajar kepada siswa perlu adanya arahan dari guru. Selain itu, pengembangan buku ajar fisika berbasis STEM perlu dilakukan dengan mengkaji pada materi lain sesuai dengan kebutuhan.

\section{DAFTAR PUSTAKA}

Akbar, S. (2015). Instrumen Perangkat Pembelajaran. Bandung: Remaja Rosda Karya

Almuharomah, F. A., Mayasari, T., dan Kurniadi, E. (2019). Pengembangan Modul Fisika STEM Terintegrasi Kearifan Lokal "Beduk" Untuk Meningkatkan Kemampuan Berpikir Kreatif Siswa SMP. Berkala IImiah Pendidikan Fisika, 7(1), 1-10

Arikunto, S. (2010). Prosedur Penelitian Suatu Pendekatan Praktik. Jakarta: Rineka Cipta

Aristawati, N. K., Sadia, I. W., dan Sudiatmika, A. A. I. A. R. (2018). Pengaruh Model Problem Based Learning terhadap Pemahaman Konsep Fisika Siswa SMA. Jurnal Pendidikan Fisika Undiksha, 8(1), 31-41

Bozkurt, A., Ucar, H., dan Idin, S., (2019). The Current State of The Art in STEM Research: A Systematic Review Study. Cypriot Journal of Educational Science, 14(3), 374-383

Moore, T. J., Stohlmann, M.S., Wang, H. H., Tank, K. M., Glancy, A. W., dan Roehrig, G. H. (2014). Implementation and Integration of Engineering in K-12 STEM education. Engineering in Pre-College Settings: Synthesizing Research, Policy, and Practices. Purdue University Press, 35-60

Nessa, W., Hartono, Y., dan Hiltrimartin, C. (2017). Pengembangan Buku Siswa Materi Jarak pada Ruang Dimensi Tiga Berbasis Science, Technology, Engineering, and Mathematics (STEM) Problem Based Learning di Kelas X. Jurnal Elemen, 3(1), 1-14

Pangesti, K.I., Yulianti, D., dan Sugianto. (2017). Bahan Ajar Berbasis STEM (Science, Technology, Engineering, and Mathematics) Untuk Meningkatkan Penguasaan Konsep Siswa SMA. UPEJ Unnes Physics Education Journal, 6(3), 53-58

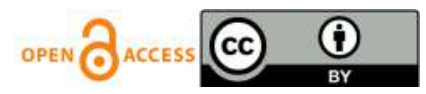


Pengembangan Buku Ajar...

Rachmawati, D., Suhery, T., dan Anom, K. (2017). Pengembangan Modul Kimia Dasar Berbasis STEM Problem Based Learning Pada Materi Laju Reaksi Untuk Mahasiswa Program Studi Pendidikan Kimia. Seminar Nasional Pendidikan IPA, 1(1), 239-248

Rusyati, R., Permanasari, A., dan Ardianto, D. (2019). Rekonstruksi Bahan Ajar Berbasis STEM Untuk Meningkatkan Literasi Sains dan Teknologi Siswa pada Konsep Kemagnetan. Journal of Science Education and Practice, 2(2), 10-22.

Sugianto, D., Ahied, M., Hasi, W. P., Wulandari, A. Y. R. (2018). Pengembangan Modul IPA Berbasis Proyek Terintegrasi STEM pada Materi Tekanan. Natural Science Education Research, 1(1), 28-39

Suryana, A., Utami, I. S., Septiyanto, R. F., dan Wibowo, F. C. (2017). Pengembangan STEM-A Berbasis Kearifan Lokal dalam Pembelajaran Fisika. Jurnal IImiah Pendidikan Fisika Al-Biruni, 6(1), 67-73

Syahirah, M., Anwar, L., dan Holiwarni, B. (2020). Pengembangan Modul Berbasis STEM (Science, Technology, Engineering, and Mathematics) Pada Pokok Bahasan Elektrokimia. Jurnal Pijar Mipa, 15(4), 317-324

Tegeh, I. M., Jampel, I. N, dan Pudjawan, K. (2014). Model Penelitian Pengembangan. Yogyakarta: Graha Ilmu.

Yuanita, Y., dan Kurnia, F. (2019). Pengembangan Bahan Ajar Berbasis STEM (Science, Technology, Engineering, and Mathematics) Materi Kelistrikan Untuk Sekolah Dasar. Profesi Pendidikan Dasar, 1(2), 199-210 